\title{
嚥下第II期における嚥下圧動態の研究
}

愛媛大学医学部耳鼻咽喉科学教室（主任：柳原尚明教授）

森敏 裕

\section{INTRALUMINAL PRESSURE PROFILES IN THE PHARYNGEAL PHASE \\ IN BOTH NORMAL AND ABNORMAL SUBJECTS}

TOSHIHIRO MORI, M.D.

Department of Otolaryngology-Head and Neck Surgery, Ehime University School of Medicine, Ehime

Intraluminal pressure change in the pharyngeal phase of swallowing was measured by the station pull-through method, in which a pressure transducer probe was being withdrawn at each 1 $\mathrm{cm}$ step from a segment 25 to $8 \mathrm{~cm}$ from the nostril. The probe had an outside diameter of $5.0 \mathrm{~mm}$ in size and was loaded with two miniature pressure transducers $3 \mathrm{~cm}$ apart from each other.

Electromyogram of the suprahyoid muscles was simultaneously recorded with a surface electrode as an idex of the second phase of deglutition. The three formats to analyze pressure wave forms in swallowing were designed as followings ; a swallowing pressure curve showing peak values at each level, a conduction curve of swallowing pressure indicating the times when the peak of the pressure appeared at each level, and a calculation of the onset of relaxation and its duration at the portion of high pressure zone of the upper esophagus (UHPZ).

Analyses of the data in 30 normal subjects revealed the following results. 1) All showed swallowing pressure curves with 3 peaks at the levels of the velopharynx, hypopharynx and cervical esophagus. 2) Normal ranges of the pressure at each level of the peak were $48.2-139 \mathrm{mmHg}$, 46. 4-132 $\mathrm{mmHg}$ and 9. 0-111 $\mathrm{mmHg}$, respectively. 3) Conduction curves of swallowing pressure showed an "S" like figure in all and the gradient was steep at the level of the oropharynx and hypopharynx. 4) The duration of relaxation at the paroximal end within the UHPZ was shorter than that at the distal in all. The normal range of the duration of relaxation at the paroximal end was $365-833 \mathrm{msec}$.

Profiles of swallowing in 130 patients with dysphagia showed the following results. 5) Pressure curves in swallowing were classified into 4 pathological patterns of curve depending on the site of a lesion. 6) Two of all showed an abnormal pattern of the conduction curve, which was supposed to be origined by a disorder in the preprogrammed process in swallowing. 7) Two of all also showed abnormally earlier onset of relaxation within the UHPZ. 8) Of all, 3 showed short duration of relaxation within the UHPZ abnormally.

Key words : 睘下障害, 咽頭食道内圧, 食道入口部

A $95-1022-50022$

はじめに

嶼下第II期の生理および病態の研究にはX線透視,
筋電図，舆下圧の測定などが用いられているが，噯下 第II期が短時間のしかも極めて複雑な運動であるため 
になお十分に解明されていない，例えば誤嚥は德下第 II 期に起こる重大な病態であるが，與下第II期につい ての知識が不十分なためその治療法も予防法も確立さ れていないのが現状である。睘下第II期の嬩下圧動態 の研究は以上の意味で病態生理学的意義が大き?, 䜩 下圧の測定が臨床検查法として確立されることが望ま れている由縁である。矌下第II期の與下压の測定は 1950年代に開発されたカテーテル法,すなわち間接法 による測定から”，小型体内圧トランスデューサーを 応用した直接法へと移行しつつある゙2.しかし, 促来の 方法では測定結果の再現性などに問題があり 、また， 曣下障害症例に扔ける睘下圧測定の病態生理学的意義 に関する研究も少ないいー7》著者は正常者, 磺下困難症 例に㧍ける嚥下玨測定の方法, 測定の結果を検討し， 本法が臨床検査法として有意義であると考えられたの でここに報告する。

\section{第 I 章。羁下圧測定法の検討}

德下圧測定に関しては以下の諸点で結論が得られて いる 8 .すな⿰七，1）測定装置として小型体内圧トラ ンスデューサー法が優れている，2）受圧方向が前方あ るいは後方に一定している必要がある，3）受圧部の大 きさが測定値に影響する，4）受圧部と粘膜の相互運動 により圧值に変化をたす，5）検査に用いるbolus の 1 回量は 2 から $20 \mathrm{ml}$ の範囲が適当，6）啌・咽頭を 広範に麻酔してはならない，7）測定体位は立位,座位, 仰臥位，いずれでも良い。以上の諸点を考慮し測定結 果の信頼性を更に高めるため以下の項目について実験 的に検討した。

\section{1. 予備実験}

予備実験1）から3）の対象は正常ボランティア1名 (30歳男性) である.

1) Bolus $の$ 水温

一般に小型体内圧トランスデューサー法では圧セン サーに温度特性があるとされているが, 本研究で用い た圧トランスデューサー(ミラー社製, モデル SPC761)では，23〜 38 Cの間では $\pm 1 \mathrm{mmHg} \mathrm{BSL}$ (直線性 誤差）で無視し得る範囲にある。人体内での温度特性 を確認するため, 上記対象者に $37^{\circ} \mathrm{C} と 25^{\circ} \mathrm{C}$ 水 $5 \mathrm{ml}$ を 飲ませて下咽頭の噮下圧をそれぞれ30回測定した。水 温が $37^{\circ} \mathrm{C}$ と $25^{\circ} \mathrm{C}$ の時の暖下玨の平均值士標準偏差は, それでれ $86.1 \pm 5.06 \mathrm{mmHg}, 88.7 \pm 5.18 \mathrm{mmHg}$ であ り， $\mathrm{t}$ 検定て両者間に $5 \%$ の危険率で有意差を認めな かった。

\section{2）喉頭運動と圧センサー部のずれ運動}

外径 $5.0 \mathrm{~mm}$ の圧測定プローベを経鼻的に頸部食道 まで挿入し水 $5 \mathrm{ml}$ を與下させ, 側面からX線透視し 1 秒間30フレームをビデオテープに録画した。再生画像 より, 魷下時の唉頭の上下運動と圧センサー部の上下 運動を1フレーム毎に対比して，28烴下を解析した。 その結果, 德下時の圧センサー部の上昇距離は, 圧セ ンサーが軟口蓋部から頸部食道までいずれの部位にあ つても約 10〜15mmで，嗢下時喉頭挙上距離の約 1/3〜1/2であった。 また圧センサーの位置にかかわら ず圧センサーと喉頭はほほ同時に上昇・下降した。

3）圧測定プローベの外径

压センサーを挿入する胃管の径を変えることにより 外径の異なる圧測定プローべを試作した。胃管は外径 $4.1 \mathrm{~mm}(12 \mathrm{~F}), 5.0 \mathrm{~mm}(14 \mathrm{~F}), 7.7 \mathrm{~mm}(20 \mathrm{~F})$ の 3 種類を用い，上記対象者の水 $5 \mathrm{ml}$ 㖟下について検討し た。曣下圧はいずれの部位でも外径 $5.0 \mathrm{~mm}$ が最も高 い值を示し，軟口蓋部（前鼻孔より $12-13 \mathrm{~cm}$ ) では平 均 $85 \mathrm{mmHg}$, 下咽頭 (前鼻孔より $17-18 \mathrm{~cm}$ ) では平均 $78 \mathrm{mmHg}$ で, 外径 $4.1 \mathrm{~mm}$ 抢よび $7.7 \mathrm{~mm}$ いずれに対 しても有意に高かった（ $\mathrm{P}<0.05 ， \mathrm{t}$ 検定）（図 1$)$. また食道入口部（前鼻孔より $18-21 \mathrm{~cm}$ ) の静止時陽圧 も 10-32mmHg と外径 $5.0 \mathrm{~mm}$ が最も高い值を示した (図 2).

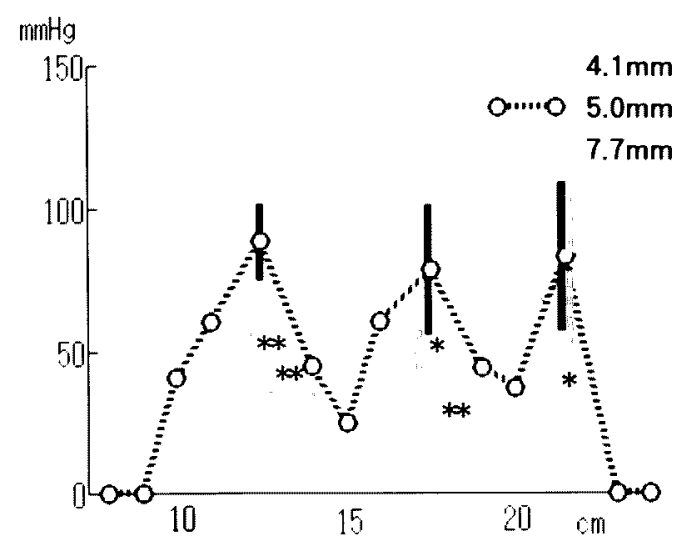

図 1 測定プローべの外径の違いによる曣下圧の 変動

横軸は前鼻孔からの距離を示す。 $\diamond, \bigcirc$, $\square$ 各部の平均値, 縦棒は軟口蓋部, 下咽 頭，および頸部食道での土1SDを示す。 (** $\mathrm{p}<0.01: 5.0 \mathrm{~mm}$ と $4.1 \mathrm{~mm}$ あるいは $7.7 \mathrm{~mm}$ との差, ${ }^{*} \mathrm{p}<0.05: 5.0 \mathrm{~mm}$ と 4. $1 \mathrm{~mm}$ との差) 


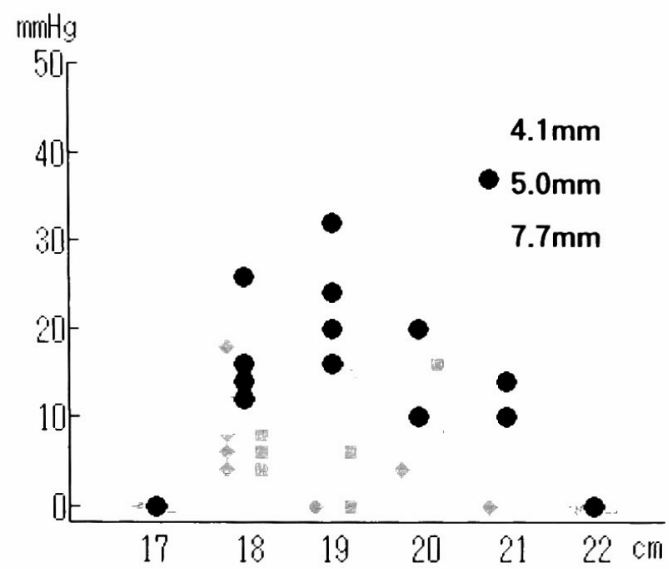

図 2 測定プローベの外径の違いによる食道入口 部静止圧の変動

横軸は前鼻孔からの距離を示す。

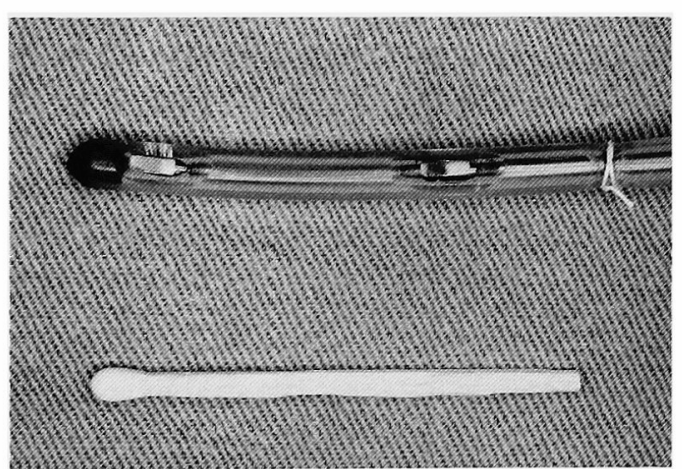

図 3 圧測定プローベ

\section{2. 測定の再現性}

1）嬹下圧測定法

圧測定には 2 チャンネル型の小型体内压トランスデ ューサー（Millar 社製 Model SPC-761，外径6 F) を 使用し，2つの圧センサー間距離を $3 \mathrm{~cm}$ とした.この 圧センサーを外径 $5.0 \mathrm{~mm}$ の胃管内に挿入し, 受圧部 が胃管の側方に設けた小孔に面するように絹系で縛 り，圧測定プローベとした(図 3 ). 圧トランスデュー サーの出力は, 直流増幅器 (SAN-EI 1253A) を経て ビジグラフ (SAN-EI 5L) に記録した。同時に, 頣下 部正中に双極表面電極を設置し舌骨上筋群の活動電位 を記録し嬩下開始時の指標とした。まず圧測定プロー べを経鼻的に前鼻孔から $25 \mathrm{~cm}$, 頸部食道まで扦入し, 同部より前鼻孔から $8 \mathrm{~cm}$ の軟口蓋部までの間, $1 \mathrm{~cm}$ 毎 に曣下時の内圧を測定する stationary pull-through 法を用いた。各部で 2 回測定すると圧センサー 2 系統
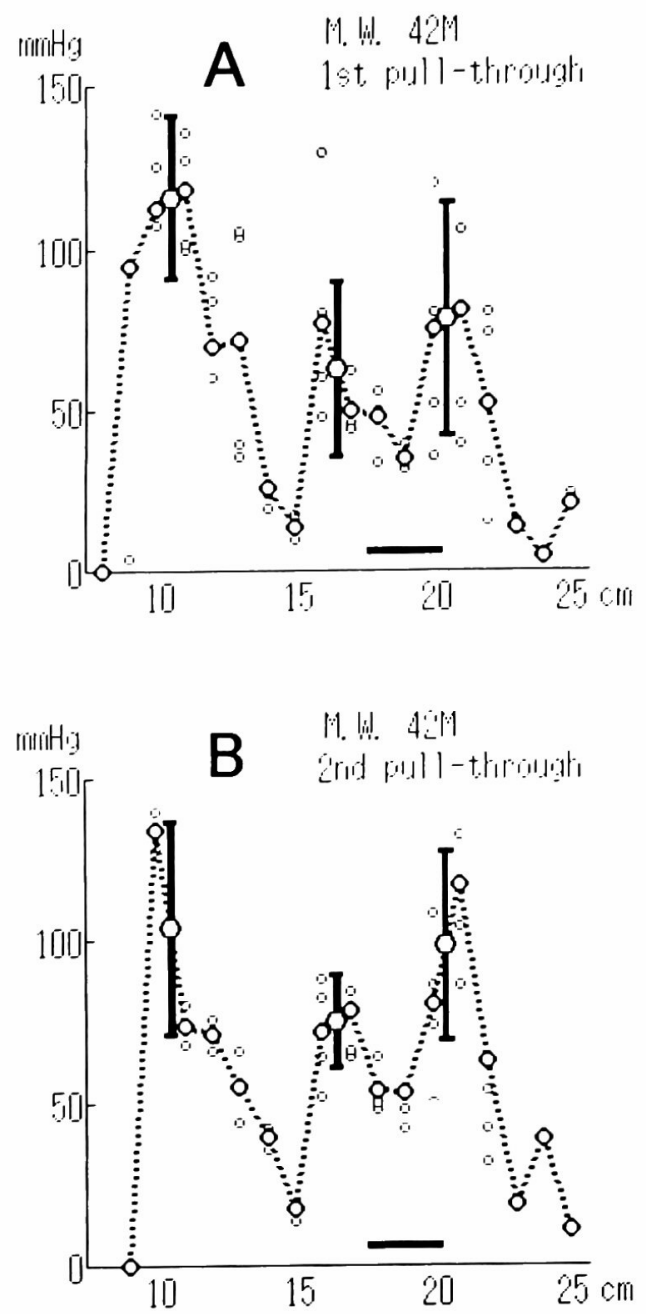

図 4 Station pull-through 法の再現性（同一日 の場合)

A：1回目, B：2 回目. ○と緹棒は各峰に 一致した部位での嚥下圧値の平均値と士 $1 S D$ を示す 横軸に平行な棒線は食道入口 部を示す

の出力が得られるので, 前鼻孔から 25-23cm では各ま 定部位で 2 個， $22-8 \mathrm{~cm}$ では各測定部位で 4 個のデ. 夕が得られる. Bolus として $25^{\circ} \mathrm{C}$ 水 $5 \mathrm{ml}$ を用い, 定中は受圧部が常に被験者の前方を向くようにした.

2) 嶼下圧の再現性

正常者 16 人（男性 9 人, 女性 7 人, 年歯 $26 \sim 60$ 歳, 平均44.5歳)で，2 回 stationary pull-through 法でં 定した舆下圧について, 再現性を検討した。図 4 は; 述の嚥下圧曲線の表示法に従い, 代表例(41歳, 女性 の 1 回目と 2 回目の測定結果を示したもので, 各部 
測定值の再現性が良好なことが分かる。各被験者の軟 口蓋部、下咽頭, および頸部食道での䠢下圧の平均值 の 1 回目と 2 回目の相関をみると, 軟口蓋部や下咽頭 では両測定間の相関係数は 0.898 抗よび $0.866 て ゙$ 再現性 は良好であるが, 頸部食道では同一個体内でも與下圧

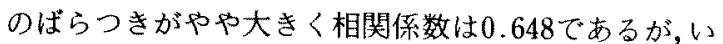
ずれも $1 \%$ 危険率で有意の相関を示した。また上記 16例中, 日を変えて複数回の曣下圧測定を行った 6 例 について測定值の再現性を検討するといずれも良好な 再現性がみられた，図 5 に代表例（60歳，女性）を示 す.

\section{3. 考案}

1）輏下纴測定法について

小型体内圧トランスデューサーの久点は機種によっ ては温度感受性が比較的大きいことにあるが，今回使 用した機種では温度の影響は無視しうる範囲で, $25^{\circ} \mathrm{C}$ と $37^{\circ} \mathrm{C}$ の水嬩下時の下咽頭での嶼下压值に有意の差を 認めなかった。咽頭や頸部食道は横紋筋で構成されて いるので一定の範囲内では bolus の温度によって䜩下 压が左右されない站えられている，以上の理由か ら本研究では bolus として, 容易に安定した温度が維 持できる $25^{\circ} \mathrm{C}$ 室温の水を用いた。

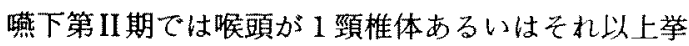
上し ${ }^{101111}$ ，ま大咽頭後壁粘膜もかなり上昇するとされ ている ${ }^{12)}$.もし喉頭挙上時に圧センサーが全く動かな ければ，噮下前と嚥下中では異なった部位の圧を測定 することになる．今回の実験結果では蜳下第II期にお いて，㬋頭と圧センサーは同じような上下運動，すな わちほほ同時に挙上を開始し，ほほ同時に下降してい た. 圧センサーの上下運動は喉頭の挙上ではなく軟口 蓋の運動に起因しているので両者の挙上距離に約 $1 / 2$ 頸椎体程度（約 $1 \mathrm{~cm}$ ) の差異はあるが，この程度の湘 定部位の違いは，常に一定方向へのずれであること， 部位によってその程度が一定していること,の 2 点か ら誤差としては問題の無い範囲と言える。喉頭運動に 関連したもう一つの注意点は，圧センサーと測定部位 のずれ運動により測定值が真の值より高くなる可能性 である、先端を曲げた硬いプローベを使用するとこの 誤差が大きいことが知られている ${ }^{13)}$ が，今回使用した プローべは比較的柔軟で曲りもなく，上記のずれ運動 による誤差も無視し得るものと考えられる。

プローべの外径と咽頭部の㬈下圧値の関係について は, $2.8 \mathrm{~mm}$ で $36 \mathrm{mmHg}^{(4)}, 3.2 \mathrm{~mm}$ で $66 \mathrm{mmHg}^{15)}$, $5 \mathrm{~mm}$ で $128 \pm 32 \mathrm{mmHg}^{16)}$ と報告されており, 外径が
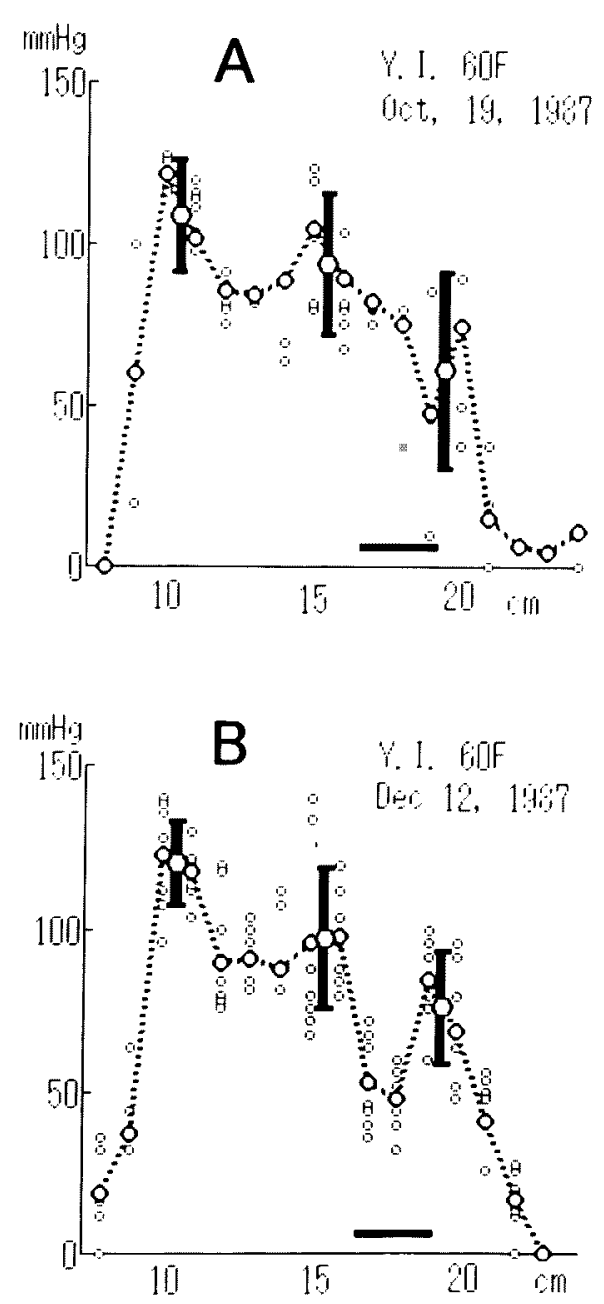

图 5 Station pull-through 法の再現性（日を異 にした場合)

A：1回目, B：2 回目. Oと縦棒は各峰に 一致した部位での嶼下圧值の平均值とさ 1SD を示す。横軸に平行な棒線は食道入口 部老示す

大さくなると嬩下圧値が高く測定される傾向がある。 一般にプローべ外径が大きい方が压值が大きく測定誤 差を小さくできると考えられるが，プローべが太すぎ ると異物感が強くなり生理的状態の值とは言えなくな る。寒際上は外径 $6 \mathrm{~mm}$ 程度が限界である。今回の測定

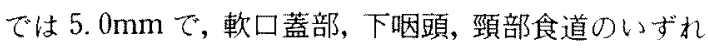
の部位でも最も高い圧が記録され，径 $6 \mathrm{~F}$ の圧センサ 一を胃管内に挿入してプローベとして使用する場合は 胃管の外径としては $14 \mathrm{~F}(5.0 \mathrm{~mm})$ が最適と思われる。 次にプローベの外径と食道入口部の静止圧の関倸をみ 
ると，小型体内圧トランスデミーサーを用いた外径 $4 \mathrm{~mm}$ のプローベでは 3 $4 \mathrm{mmHg}^{17)}$, 外径 $2.2 \mathrm{~mm}$ の カテーテル法では $6.7 \mathrm{mmHg}^{18)}$ の低い静止圧が報告 されて抢り，今回の実験でも外径 $4.1 \mathrm{~mm}$ では0 〜22mmHg と低い圧を示した, 食道入口部の静止圧は 主に輪状咽頭筋の恒常的な収縮により発生していると されており，その圧值は同筋の「張力一長さ」特性に よりプローべ外径に比例するとされている プローベ外径が 2-4mm と細いと同筋の張力は小さ く, 静止時内圧は主に粘膜下静脈叢等の軟部組織圧の みを反映するため, 上記のようなごく低い圧值しか得 られないものと推察される。食道入口部をbolusが通 過できるかどうかには食道入口部の静止圧值の高低は あまり意味がなく，輪状咽頭筋の持続的収縮と弛緩に 対応して静止圧が有るか無いかの判定が確実に行える ことが重要である。外径 $5.0 \mathrm{~mm}$ では図 2 に示すよう に必ず $10 \mathrm{mmHg}$ 以上の静止圧を示して招り，食道入 口部の弛緩による平圧化の判定にも外径 $5.0 \mathrm{~mm}$ が最 も適していると考えられる。このように食道入口部の 静止圧值や各部における䜩下埴は圧測定プローベの 径によって異なることを十分に承知しておく必要があ る.

2）德下圧の再現性について

Stationary pull-through 法により得られる曣下圧 の再現性を多数例で検討した報告は少ない20).今回16 人の検討では, 1 回目と 2 回目の同法に上る嚥下圧の 再現性は良好で, 特に軟口蓋部や下咽頭では十分な相 関が認められた。日を変えて測定した6例でも，嬩下 圧曲線の再現性は良好であり，本法が十分信頼できる 検查法であることが確認できた。

6. 小括

曣下圧測定法の信頼性を検討し，次の結果を得た。

1）使用するbolusとしては室温の水で良い，2）プロ 一べ外径は径 6 F の圧七ンサーを使用する場合は，

$5.0 \mathrm{~mm}$ 程度が良い．3）喉頭と压センサーはほぼ平行 して運動し, 両者の相対的位置の変動による測定誤差 は無視し得る。4）測定した嚥下圧の再現性は良好であ る.

\section{第II章．正常喏下における検討}

\section{1. 対象と測定方法}

咽喉頭に視診上異常がなく，曣下困難を自覚してい ない成人 30 名（男性15名, 女性15名）を正常対象とし て検討した。対象の年齢分布は26歳から60歳で平均
43.3歳。嚥下圧測定と舌骨上筋群筋電図の同時記録任 前章で述べた通りである。

2. 噮下圧剆定で得られる三つのパラメータ

正常代表例の圧波形・舌骨上筋群筋電図の同時記鈞 を図6に示したＡは近位側圧センサーが前鼻孔か巳 $10 \mathrm{~cm}$ の軟口蓋部，遠位側センサーが前鼻孔から $13 \mathrm{~cm}$ の中咽頭に位置した時の水嚥下の圧波形および筋電医 で，同様にB は前鼻孔から $13 \mathrm{~cm}$ の中咽頭と $16 \mathrm{~cm} \sigma$ 。 下咽頭，C屿前鼻孔から $14 \mathrm{~cm}$ の下咽頭と $17 \mathrm{~cm}$ の良 道入口部, $\mathrm{D}$ は前鼻孔から $18 \mathrm{~cm}$ の食道入口部と $21 \mathrm{~cm}$ の頸部食道にセンサーが位置した場合を示している。 これら原波形から，曣下圧曲線，㺞下圧伝搬曲線，食 道入口部内圧波形の 3 つのパラメータが抽出できる。

A）嚥下圧曲線：嚥下力の指標として, 嚥下圧主波て

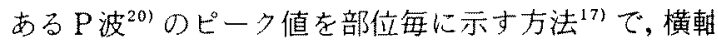
に測定部位を $1 \mathrm{~cm}$ 単位で示し, 新軸に $\mathrm{P}$ 波のピーク估 (図6の下向き知印) $\mathrm{mmHg}$ 単位で示す。部位毎の 平均值を結んだ折机線グラフを睘下圧曲線と呼ぶ（匟 7 )。な扢，食道入口部(静止時陽圧を示す上部食道高 圧帯）の前鼻孔からの距離は個人差があるので，横軽 に平行につけた水平線で表示した。

B）嶼下圧伝搬曲線：嚥下圧波の伝搬様式の解析を 目的として鰙下圧伝搬曲線法を考案した ${ }^{211}$. 綐軸に測 定部位を $1 \mathrm{~cm}$ 単位で示し, 横軸に舌骨上筋群筋放電活 動開始点（図 6 の斜め上向き矢印）を基準とした時刻 を示し，各部に扔ける $\mathrm{P}$ 波の頂点(図60下向矢印) の時刻を記す方法で，部位毎の平均值を結んだ折れ線 グラフを睘下圧伝搬曲線と呼んだ(図 8 )。なお，食道 入口部は縦軸に平行につけた䌅線で示した。

C）食道入口部圧波形分析：食道入口部では静止圧 値や曣下圧值自体はあまり重要ではなく, bolusが通 過できるように，適切な時期に十分な時間平圧化して いるかどうかが重要である．平圧化 (弛緩) 開始時期 は，舌骨上筋群筋電図上の德下第II 期開始点（図 6 の 斜め上向き矢印）を基準とした。平压化時間は静止时 陽圧が大気圧まで低下した時点から $\mathrm{P}$ 波の立ち上がり 部分（図6の最初の上向き小矢印）迄とした。

3 . 結果

A) 正常嚥下圧曲線

正常呬下圧曲線は, 軟口蓋部, 下咽頭, 頸部食道に ピークを持つ 3 峰性を示す ${ }^{22)}$ (図 7 )。峰の部位は体型 により個人差を示すが，大凡，軟口蓋部の峰は前鼻孔 より $11-12 \mathrm{~cm}$, 下咽頭の峰は $16-17 \mathrm{~cm}$, 頸部食道の峰 は20-21 cm の部位にある。食道入口部は $17-19 \mathrm{~cm} \sigma$ 


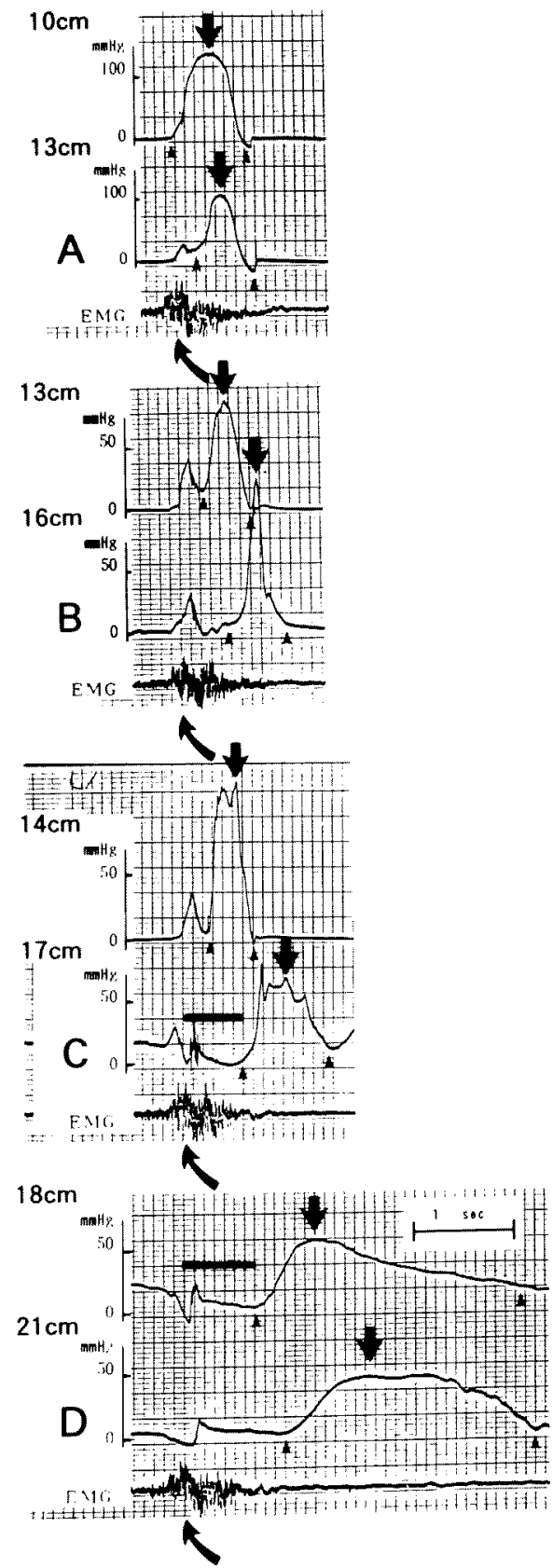

図 6 正常德下生波形々表面笳電図. A：ヒンサ 一の位置は前鼾孔加号 $10 \mathrm{~cm} と 13 \mathrm{~cm}$, 同様 に, B: $13 \mathrm{~cm} と 16 \mathrm{~cm}, \mathrm{C}: 14 \mathrm{~cm}\llcorner 17 \mathrm{~cm}$, $\mathrm{D}: 18 \mathrm{~cm}$ と $21 \mathrm{~cm}$. 下向きの矢印はP波の ピーク在，上向きの小三角印はP 波の開始 点と終了点を，斜め上向きの矢印は筋電図 上䱇下第II 期の開始と考えられる点を， $17 \mathrm{~cm} \cdot 18 \mathrm{~cm}$ の水平棒線は食道入口部の平 圧化時間を示している。

$\mathrm{EMG}$ ：舌骨上筋群表面筋電図.

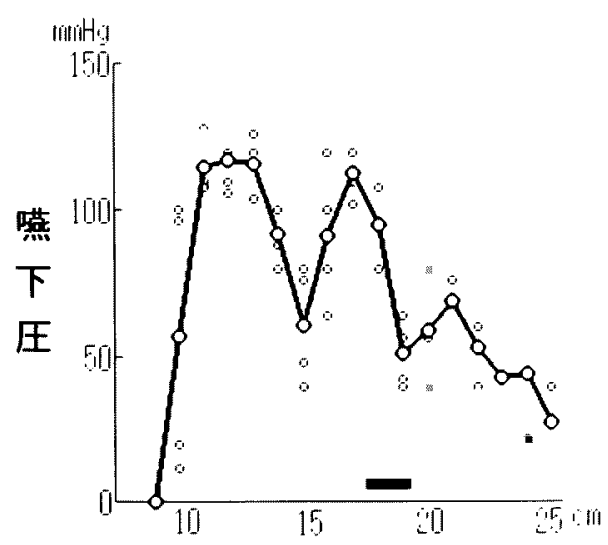

\section{前鼻孔よりの距離}

図 7 代表的な正常嬩下圷曲線

备部 4 與下の測定值とその平均を示す。横 軸に平行な棒線は食道入口部を示す

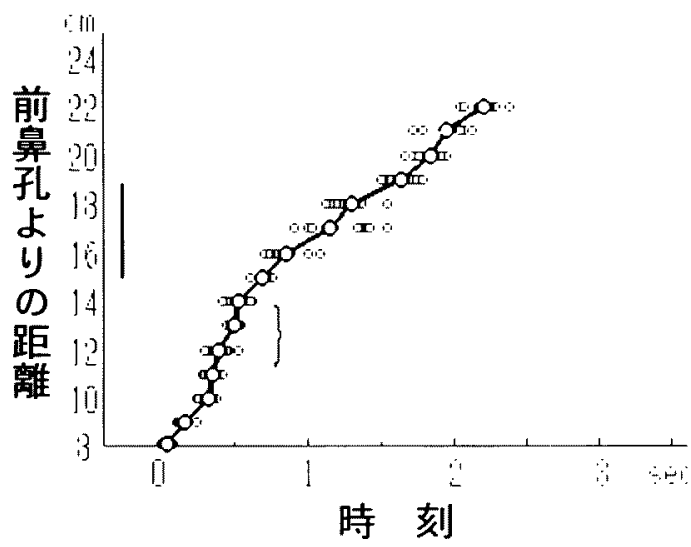

图心代表的な正常德下圧伝搬曲線

維軸に平行な棒線は锭道入口部，括弧は中 下咽頭部示示 本曲線は嚥下圧の発生時 期をみるものであるいで，横軸は舌骨上筋 電龱活動它基準とした時刻表示とした。

部位に始まり2 $4 \mathrm{~cm}$ の幅を示した。. 各峰の代表値の求

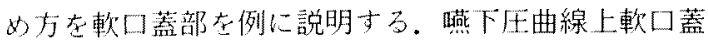

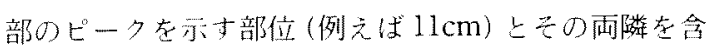
む3 部位(例之ば $10 \sim 12 \mathrm{~cm}$ ) での矄下生は各人そ机ぞ 扎近似しており，さ扎的3 部位での計12器下の值が 軟口蓋部心曣下世を代表するものと考えた３0人ての 計3600データをもとに，PC-SAS解析システム党用 いて以下の統計好理を行った。 Shapiro-Wilk 統計亩 Wは0.950であり，正規分布からのランダム標本である と推計点扎た。平均值93.5，標準偏差23.1であり，95 
$\% の$ 信頼区間（平均值士1.96SD）は48.2-139であり， $48 \mathrm{mmHg}$ 以下あるいは $140 \mathrm{mmHg}$ 以上をはずれ值と した(表1)。

B）正常曣下圧伝搬曲線

曣下圧伝般曲線の正常代表例を図 8 に示した。正常 者では軟口蓋部ではやや緩徐, 中咽頭から下咽頭にか けては急峻(図中の括弧で示した部位)，食道入口部か ら頸部食道までは再び緩徐になるS字状の曲線をな す．各部におけるP波の伝搬速度はこの曲線の勾配に よって示され，中一下咽頍で最も速く伝搬される。

C) 正常食道入口部内压波形

食道入口部は嚥下圧測定上静止時（非睘下時）に持 続的陽圧を認める部位と定義される。同部は通常、前 番孔から 16〜18cm の部位に始まり2〜 $4 \mathrm{~cm} の$ 幅をも って存在する.この食道入口部の内最も上方の測定部 位 (咽頭端) と下方り測定部位（食道端）では, 図 6 の代表例に示すように平圧化時期 時間ともに異なる ことが明らかになった（図6の例の食道入口部は 17 〜 $20 \mathrm{~cm}$ であった). 全員平圧化時期注食道端がやや早 々，平圧化時間は食道端が長かった。

平圧化開始時期の信頼区間：各人咽頭端（例えば前

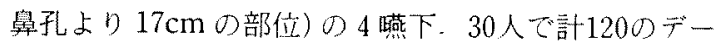
夕を基に, 臙下圧曲線の場合上同様の統計学的手法に より代表值を求めた。咽頭端での舌骨上筋群活動開始 点と平圧化開始時期の時刻差は $76 \pm 106 \mathrm{msec}$ (平均土 標準偏差)で，95\%信頼区間は-132〜284msecであ り,一133msec 以下あるいは285msec 以上をはずれて值 とした，食道端でも同様に代表值を求めると，舌骨上 筋群活動開始点と平圧化開始時期の時刻差法 $-141 \pm$ 192msecで，95\%信頼区間はー518〜235msecであ り, $-519 \mathrm{msec}$ 以下あるいは $236 \mathrm{msec}$ 以上をはずれ值 とした (図9).

平圧化時間の信頼区間：上記と同様に算出すると, 平圧化時間は咽頭端で最も短く $598+120 \mathrm{msec} て ゙ 95 \%$ 信頼区間は 363〜833msecであり，362 msec 以下ある いは $834 \mathrm{msec}$ 以上をはずれ值とした。食道端では平圧 化時間が長く $1218 \pm 260 \mathrm{msec} て ゙ 95 \%$ 信頼区間は 708 〜 1728msec であり，707msec 以下あるいは 1729msec 以上をはずれ值とした（図 9).

\section{4. 小括}

嚥下圧測定から得ら机たデー夕をもとに，嚥下压曲

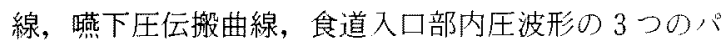
ラメータを抽出した。嚥下圧曲線では 3 部位の平均值 抢よび信頼区間を設定した。瞧下圧伝搬曲線では各部
表 1 正常率下圷曲線の 3 峰の正常範囲 (单位は $\mathrm{mmHg}$ )

\begin{tabular}{|c|c|c|c}
\hline 部 位 & 軟口蓋部 & 下咽頭 & 頸部食道 \\
\hline 平均値 & 93.5 & 89.3 & 60.2 \\
標準偏差 & 23.1 & 21.9 & 26.1 \\
正常範围 & $48.2-139^{*}$ & $46.4-132^{*}$ & $9.0-111^{*}$ \\
\hline
\end{tabular}

(*平均 $\pm 1.96 \mathrm{SD})$
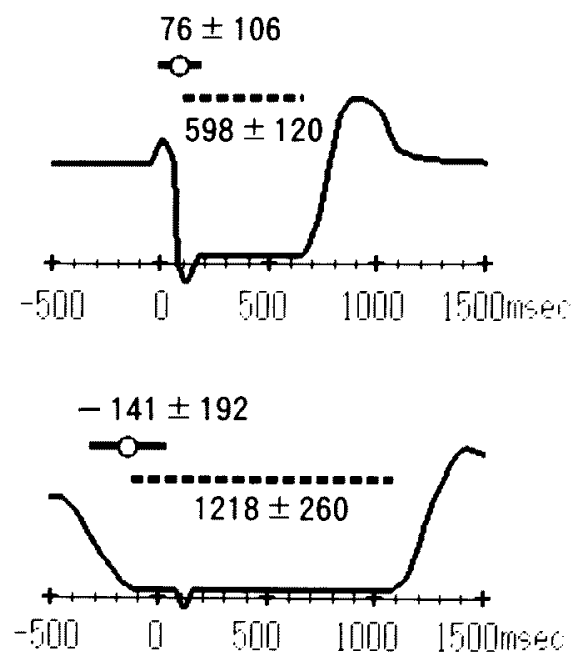

図 9 食道入口部内圧波形の模式図

○水平棒線は正常 30 例での平圧化開始時 期の平均と標準偏差, 水平破線は平压化時 間の平均を示す 横軸は筋電図を指標とし た時刻を示す上段：咽頭端，下段：食道 端.

の圧発生の夕イミングが容易に読み取れることを示 し，正常パターンを明らかにした。食道入口部内圧波 形分析では，食道入口部平圧化の時期と時間が同部内 の咽䫒端と食道端で異なることを明らかにし，それぞ 扎信頼区間を設けた。なお，65歳以上の高柃者では德 下困難を訴之ない正常例でも睘下压の低下や食道入口 部弛緩異常がみられるとする報告があり ${ }^{8)}$ ，今後の検 討が必要である。

\section{第1II章. 病的嚥下における検討}

\section{1. 対象 方法}

嚥下困難を訴えた患者130症例について, 前章で述心゙ た方法で與下圧を測定し解析した。與下困難の原因の 内訳は表 2 に示した。

2. 結果 
表 2 疾患と鷬下王曲線分類の刘応

\begin{tabular}{|c|c|c|c|c|c|c|c|c|c|}
\hline \multirow{2}{*}{ 疾 } & \multirow{2}{*}{ 名 } & \multicolumn{2}{|r|}{ 嚥 } & 圧 & 曲 & 線 & 類 & & \multirow{2}{*}{ 計 } \\
\hline & & I & II a & II b & IIl a & III b & III $\mathrm{ab}$ & 不能 & \\
\hline & \multicolumn{9}{|l|}{ 経 筋 疾 患 } \\
\hline & \multirow{2}{*}{$\begin{array}{l}\text { 脳 血管 障 害 } \\
\text { 中枢性神経疾患 }\end{array}$} & 3 & & 1 & & 1 & 5 & 1 & 11 \\
\hline & & 5 & & & 2 & & & & 7 \\
\hline & 未梢性神経疾患 & 9 & & 1 & 1 & 3 & 5 & 5 & 24 \\
\hline & 反回神経麻瘴 & 8 & & & 1 & 2 & 1 & 2 & 14 \\
\hline & 重症筋無力症 & & & & & & 2 & & 2 \\
\hline & 筋 疾 患 & 2 & & & & & 6 & & 8 \\
\hline & その 他 & & & & & 1 & 1 & 2 & 4 \\
\hline 誤 & 臙 & & & & 1 & 1 & & 1 & 3 \\
\hline & $-\mathrm{V}$ 症候群 & 10 & & 2 & 1 & 1 & & & 14 \\
\hline & 化 管 腫 县 & 6 & & & 2 & & & 2 & 10 \\
\hline & 一 チ 賏室 & 5 & & 3 & & & & 1 & 9 \\
\hline & $\infty$ & 7 & 1 & 2 & 4 & 1 & 4 & 5 & 24 \\
\hline & 計 & 55 & 1 & 9 & 12 & 10 & 24 & 19 & 130 \\
\hline
\end{tabular}

(睘下圧曲線分類：I〜III b は本文参照. III abはIII a とIII bの両者の複合型，不能は一部の部位でしか測定 できなかった例を示す.)

\section{A）酸下压曲線の分類}

\section{1) 分類法}

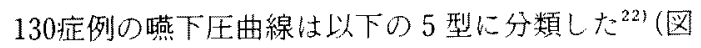
10).

1 型: 正常

II 型：異常え進型

II a 型：頸部食道の峰の圧值が異常九進する $(112 \mathrm{mmHg}$ 以上) 型

II b 型: 下咽頚の峰の圧値が異常九進する (133mmHg 以上) 型

III型：異常低下型

III a : 下咽頭の峰の圧值が異常低下する (46mmHg 以下) 型

III b : 軟口葢部の峰の圧值が異常低下する (48mmHg 以下) 型

2) 分類の結果

㺞下压曲線の型上疾患との関係を表 2 に示した。症 例の約 $40 \%$ は正常のI 型, 約33\%妒圧低下型を示した。 嚥下障害が強くすべての部位で測定を行えなかつた 症例では，测定さ扎た值が異常に低いのでIII ab 型と

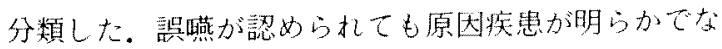
い例があり，また同じ疾患群でも嚥下動態は一定では ないので，德下压曲線分類と疾患との間に一定の対応
I 正常型

II 噄下任亢進型

a. 食道入口部 凡進型

b. 下咽頭九進型

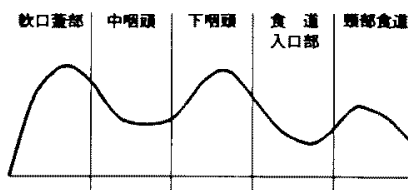

III 繁下圧低下型

。. 咽頭収舵力の 低下型

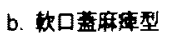

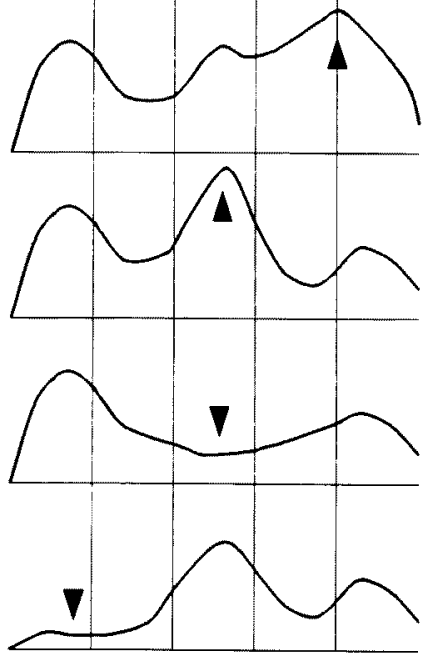

図10嬩下圧曲線分類

は东ら扎交かったが、次の上うな傾向がうかが扎たた。 1）下咽頭ポーチ・嚊室例では圧元進を示寸ことが多 い.2）脳血管傽害例のうち仮性球麻疸やワレンバルグ 

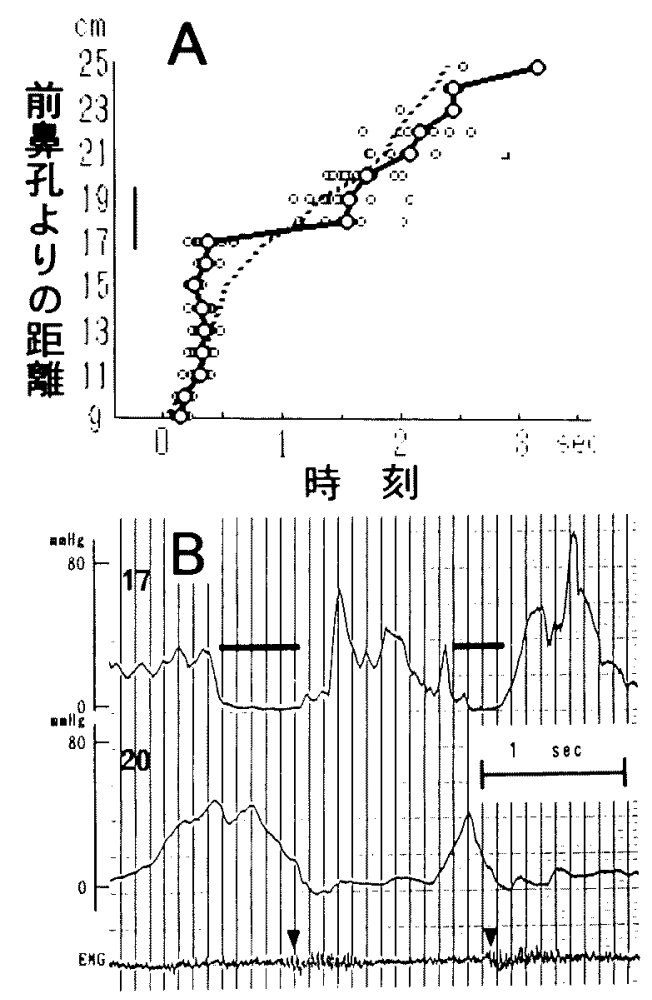

图11 A：異常曣下圧伝搬曲線の1例（点線泀正 常バターン). 本曲線は喂下压の発生時期を みるものであるので，横軸は舌骨上筋電図 活動を基準とした時刻表示とした，B：同 症例の食道入口部圧波形。上段：前鼻孔加 ら $17 \mathrm{~cm}$ では, 水平棒線で示す平压化時期 が最下段の筋電图で示さ扎る嚥下第川期の 前である，中段：前鼻孔から $20 \mathrm{~cm} の$ 頸部 食道内圧波形は正常. 下段：舌骨上筋群表 面筋電図。

症候群ではIII ab 型を示し，他はI型あるいはII b 型 を示す．3）变性疾患や頭蓋底腫演などの未梢性脳神経 麻渒例では圧低下型が多い，4）フフンンマー・ビンソン 症候群では】型が多いが，そのほとんどは正常下限の 璜下压を示市

\section{B）曣下生伝搬曲線}

曣下圧伝搬曲線が作図できたのは62例で，そのうち 60例は正常のS 字状を呈し，2例に扒いて異常を呈し た。異常はワレンベルグ症候群执よび原因不明の脳任 穴進に対する脳室シャント術後の各1例に認められ た。後者の燕下圧伝搬曲線を図11Aに示す。本例では 軟口蓋部から食道入口部まで䁵下圧が同時に発生して 抢り，適切な時間差が失われている。曂下圧曲線を作

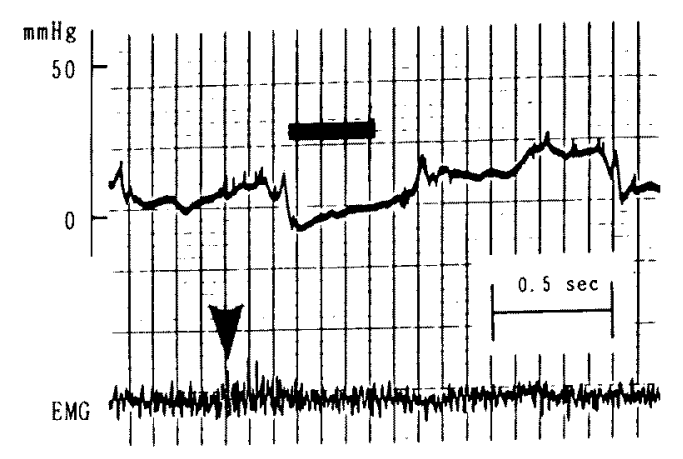

図12平圧化(弛緩) 時間異常短縮例の食道入口部 咽頭端の嘾下圧波形

平圧化時間は $340 \mathrm{msec}$.

図できなかった症例が68例もある理由は，臙下第 I 期 障害が高度で舌骨上筋群に異常放電がみら机嬿下第 II 期開始点の同定が不可能であったためで，それ自体が 異常と言える。

C) 食道入口部圧波形分析

食道入口部の平压化時期・時間としては平圧化（弛 緩）時間の短い咽頭端の値が重要であるので, 咽頭端 の值のみを分析对象とした。前記正常者群での結果を 基に, 平压化開始時期がー $132 \mathrm{msec}$ から $284 \mathrm{msec} の$ 間 に無い場合をはずれ値とし，臨床的には弛䋸時期の異 常と判定し, 同様に平圧化時間が $363 \mathrm{msec}$ 未満を臨床 的には弛緩時間の異常短縮とした。弛緩時期の異常は 2 例（異常䠢下圧伝搬曲線を呈した 2 例と同一症例） にみられ，舌骨上筋電図を基準とした平圧化開始時期 の平均はー $687 \mathrm{msec}($ 図11B) およびー240msec(図13 C)であった。他の128例のうち先に述べように舌骨 上筋群の筋電図上の活動開始点が同定できなかった68 例在除き，60例ではすべて弛緩時期は正常であった。 弛緩時間の異常短縮は 3 例（代表 1 例を図12に示す） にみられ，他の127例ではすべて正常範囲内にあった。

3. 考案

A）嚥下圧曲線について

著者は正常の㗖下珐曲線は軟口蓋部，下咽頭，頸部 養道の 3 力所にピークを持つ 3 峰性であることを既に 報告した ${ }^{221}$. 西納ら ${ }^{23)}$ ，小宮山ら ${ }^{24)}$ は上咽頭と下咽豉 にピークを持つ 2 峰性としているが, bolusの量によ らず咽頭から頸部食道までは一連の鰙下運動として每 回圧が発生するので，嬩下第II期の機能を理解するに は頸部食道の峰も含めるべきと考えている。

著者が提唱した嚥下圧曲線分類の診断上の意義を本 
A

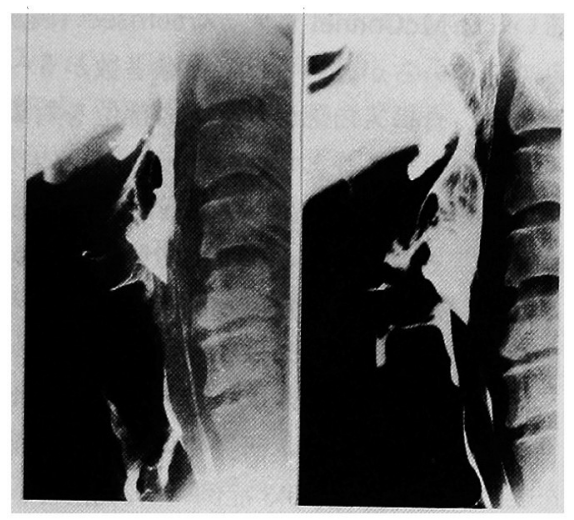

B

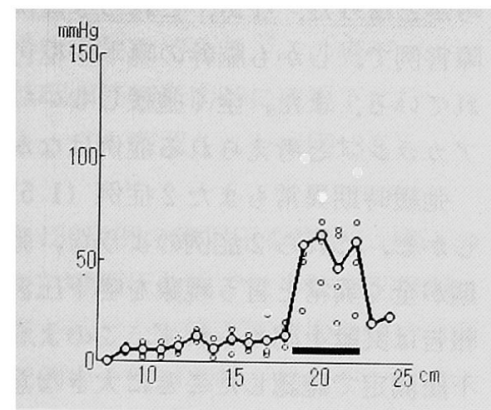

C

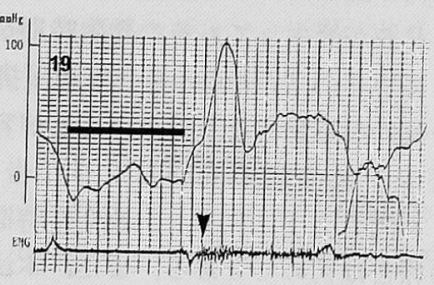

D

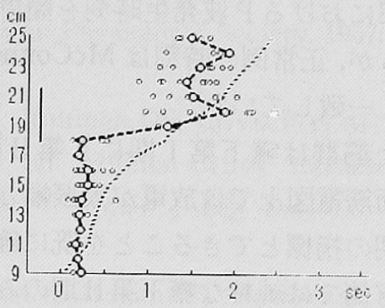

E

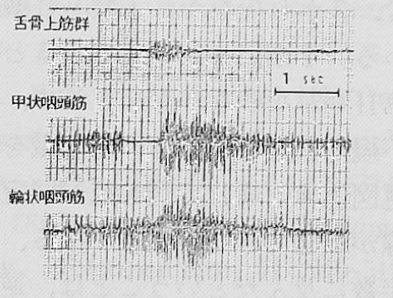

図13 ワレンベルグ症候群例

A：X線透視側面像 (左：嬩下時，右：嚥下活動終了時)。 B : 嶼 下圧曲線はIII ab 型. C : 食道入口部圧波形分析では, 平圧化時間 は正常だが平圧化時期(水平棒線) は異常である。D：睘下圧伝搬 曲線には正常と異なり圧発生の適切な時間差が失われている(点 線は正常パターン). E : 嚥下時の筋電図. 甲状咽頭筋があたかも 輪状咽頭筋のような弛緩パターンを示し, しかもその時期が嬹下 第II期の前である。また輪状咽頭筋は全く弛緩していない.

研究での観察結果からまとめると次のようになる.

II a 型：輪状咽頭噯下困難 (cricopharyngeal dysphagia)の病態を示す型で, 食道入口部の弛緩に恒 常性がない場合には誤嬹あるいは食塊の逆流が起こ り, 弛緩が正常の場合には頸部の絞扼感や曣下時の抵 抗を自覚する。

II b 型 : 食道入口部の機能的狭窄のため下咽頭で嚥下 圧の異常え進をきたす型で, 臙下動作の面からみれば 食道入口部の異常を代償するための下咽頭の機能六進 を示すものと考えられる．普通の bolusでは多少の曣 下困難を自覚するだけで俁嚥をきたすことはない。し かし, 1 回嚥下量がある限度を越えると誤嚥をきたす。 III a 型：舌根の後方への運動不全と中下咽頭収縮筋の 機能低下により十分に咽頭内圧が高まらない状態であ る。㫶下力低下に見合った bolus 量であれば, 必ずしも 誤曣をきたさない。一方その嚥下能力を越えたbolus 辇であると, 食道入口部の弛緩時間は正常でもこの間 にす心゙ての bolusがこの部を通過することは不可能 で，喉頭下降期型誤嘸をきたす

III b 型：軟口蓋麻痺の病態を示す型. 嚥下圧測定によ り軽度の軟口蓋麻疩でも診断することが可能である。

B）圜下圧伝搬曲線について

聴下第II 期には口腔側から食道側に向かうあたかも 螦動運動のような筋収縮の伝搬が行われ，その活動に 一致して嶼下圧波, $\mathrm{P}$ 波は部位毎に, ある時間差をも って出現する。この現象を $\mathrm{P}$ 波の伝搬と考え, その伝 搬速度が求められてきた ${ }^{25 / 26) 271}$. しかし, bolus 駆動 ナる上で重要なことは速度值そのものより，上流から 下流入向かって順序良く $\mathrm{P}$ 波が発生寸ることである. 嚥下圧伝搬曲線法ではこのP波発生パターンが一目瞭 
然で，例えば図11Aに示した症例では十分なピーク値 を持ったP波が発生してもその発生時期が同時あるい は逆転しているので，bolusを上下に圧排するのみで 下方への有効な駆動力たり得ないことが容易に理解さ れる。従来 $\mathrm{P}$ 波発生の協調異常が報告されてきた $か^{28)-321}$, 本例の上うに明確な $\mathrm{P}$ 波発生時期異常を呈し た症例の報告は初めてである。また，本法では咽頭・ 食道各部における $\mathrm{P}$ 波発生時刻を簡単に読みとること が出来るが, 正常例の時刻は McConnel ら ${ }^{33)}$ が示した 値と良く一致していた。

舌骨上筋群は器下第 I 期にも第II期にも活動する が、表面筋電図上では放電が大振幅となった時点を䁵 下第II期の指標とできることを既に確認している21). 與下障害例では純粋な䓵下第II期のみの障害例はむし ろまれで，多か机少なかれ I 期とII期両者の障害が含 まれている。I期障害が高度であると嚥下を意図して も嬩下第II 期がなかなか惹起されず，その間，舌骨上 筋群は不規則な振幅の大きい筋放電を続けることとな り，筋電図上嶼下第II期開始点が同定できず，嚥下圧 伝搬曲線が作図できないこととなる。今回このような 症例が半数に及んだということは，逆に言えば，蠉下 第 II 期障害例では䠢下第 I 期障害をも伴う頻度が高い ことを示している。

C）食道入口部の平圧化（弛緩）時期・時間について 食道入口部の弛緩不良，とくに弛緩時間の短縮症例 の報告では従来明らかな基準のないまま議論されてき $た^{3133435) 361}$ 食道入口部弛緩時間の異常の判定には, 当 然その正常範囲が明らかにされねばならない，食道入 口部の正常平压化時間については, Huruwitz $ら^{37) か ゙ ~}$ 200-500msec, Sokol ら ${ }^{20)}$ が 250-400msec, Duranceau
$ら^{28)}$ が $1200 \pm 100 \mathrm{msec}$, 淽沢ら ${ }^{38)}$ が $480 \sim 750 \mathrm{msec}$, McConnel ら ${ }^{331}$ が 786msec（表から計算）と報告して いるが，いず扎被験者数が 5 〜 14例と少なくまた 食道入口部の内のどの部位を対象としたかも不明な報 告があり，いまだ十分に検討されているとは言えない。 食道入口部は 2 4 $\mathrm{cm}$ の幅をもっており，本研究では その咽頭端と食道端で弛緩時間が異なることを明らか にし，この点に注意を払い食道入口部咽頭端の平压化 (弛緩)時間の信頼区間を求めた，正常人 30 名を対象と した 363〜833msec という結果は最も信頼性の高い值 と言える。本研究での食道入口部弛緩異常短縮例の頻 度は 130 例中 3 症例 $(2.3 \%)$ で，ごく少ないことが明 らかとなった。な抗，これら 3 症例はいずれも脳血管 障害例で，しかも脳幹の詈下中枢付近の障害と推定さ れている，また，全く弛緩しないいわゆる輪状咽頭筋 アカラシアと考えられる症例はなかった。

弛緩時期異常もまた 2 症例（1.5\%）でまれである. しかし,これら 2 症例のような, 弛緩はするがその時 期が全く異常と言う現象を睘下圧波形で明確に示した 報告は文献上認められず，このような病態の存在を嶼 下圧測定で確認したことに大きな意義がある。これら 2 症例は前述の上うに䍛下圧伝搬曲線も異常を呈して おう，輪状咽頭筋だけでなく多くの德下関与筋の活動

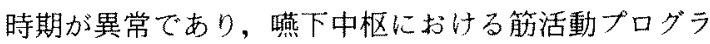

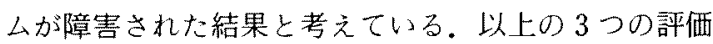
法による解析結果と疾㭧群の関係を表 3 にまとめた。

\section{4. 症例}

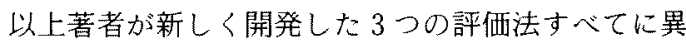
常を呈した症例を呈示しその診断的意義について述べ る。症例は65歳男性, ワレンベルグ症候群例で，突発

表 3 各疾患の曣下圧測定からみた黇下動態

\begin{tabular}{|c|c|c|c|c|}
\hline 疾患 & 病態 & 王曲線 & 伝搬曲線 & 人口部弛緩 \\
\hline \multirow{3}{*}{$\begin{array}{l}\text { 脳血管障害 } \\
\text { 神経変性疾患 }\end{array}$} & 核上性 麻瘒 & I, III型 & 正常 & 恒常性欠如 \\
\hline & 延骮道中枢障 害 & I 型 & 異常 & 時期 異常 \\
\hline & 核下性麻痺 & III型 & 正常 & 正 \\
\hline 筋 疾 患 & $\begin{array}{l}\text { 筋 力 低下 } \\
\text { 人口部抎張障害 }\end{array}$ & III型 & 正常 & 正 \\
\hline$P-V$ 症候群 & 筋 力 低 $下$ & III型 & 正常 & 正 \\
\hline ポーチ. 覟室 & 人口部弛緩異常？ & II b 型 & 正常 & 異常 ? \\
\hline 反回神経麻瘢 & 声門閉鎖不全 & I, III a 型 & 正常 & 正 常 ? \\
\hline
\end{tabular}


性䁵下不能老呈した 1 例を図13に示吉图13AはX線 透視側面像で，左の喉頭举上期にも心゙リウムbolus 仗 全く食道入口部に流入せず，口腔や腔に逆流した。 嶼下圧曲線は，軟口蓋部，下咽頭ともに圧の異常低下 を示すIII ab 型で，軟口蓋麻渒および舌根・下咽頭の運 動不良を示すものと考えられた(図13B)。食道入口部 の輏下圧波形を見ると平压化時間は正常であるが，そ の開始時期は筋電図から読及取机る臙下第 II 期開始時 期の前であり，食道入口部弛緩の時期異常が示唆され た(図13C)。嚥下圧伝搬曲線では軟口蓋部加ら下咽頭 まで時間差がなく同時に压が発生している(図13D)。 以上の検查結果は曂下第 2 期のブログラム異常と同期 に関与する筋力の異常低下を示すもので，食道透視検 査では明らかにし得ない異常である。この曣下プログ ラムの異常は, 輪状咽頭筋切断術時に直視下に行った 筋電図学的検查によっても確認さ扎た（図13E).

\section{5. 小括}

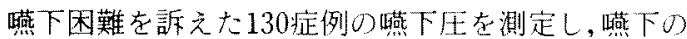
病態生理を考察した。臙下压曲線では半数が正常型， 3 分の 1 が圧低下型を示した。瞬下生伝搬曲線では同 曲線が作図できた62例中 2 例が異常を呈した，食道入 口部压波形分析では，弛緩時期異常が 2 例，弛緩時問 異常短縮が 3 例発見された。これら3つ0評価法を総 合すると複雑な暖下第II 期動態異常の詳細を把握する ことが可能となり，治療法の決定にも重要な情報を与 える。

\section{第IV章. 結}

\section{論}

1.小型体内圧トランスデューサーを用いた蟃下圧 測定では，圧トランスデューサーを選バば, bolus の温 度が咽頭・頸部食道の内圧測定結果に及ぼす影堷は無 視しうる程度である。圧測定プロー心゙としては外径 5. $0 \mathrm{~mm}(14 \mathrm{~F})$ の胃管に圧トランスデューサーを挿入 して用いるのが最適で，これを用いた stationary pull -through 法の再現性は良好である。

2. 睘下圧曲線を 5 型に分類することにより，咽 頭・頸部食道の與下圧の異常克進・低下を明らかに示 Lた.

3. 曣下圧伝搬曲線は聼下関与筋の協調運動を反映 するもので，德下時の筋活動ブログラム異常症例の診 断を容易にした。

4. 食道入口部圧波形の分析では，食道入口部心内， 咽頭端の平圧化 (弛緩) 時間が最も短いことを初めて 明らかにし，平圧化時期異常症例と平圧化時間異常短
縮例の存在を初めて客観的に示した。

5.以上の3 評伍法在総合す机壦下第III期の動態 とその障害を把握できることを示した。

\section{引用文献}

1) Code CF. Schlegel JF : Motor action of the esophagus and its sphincters, Chapt. 90 in Handbook of Physiology-Alimentary Canal. Bethesda, Maryland, American Physiologic Society, 1967, ppl8211839.

2) Millhon WA, Hoffman DE, Jarvis $P$ et al : Preliminary report on Millhon-Crites intraesophageal motility probe. Amer J Dig Dis 14: 929-933, 1968.

3) Dodds WJ, Stef JJ, Hogan WJ : Factors determining pressure measurement accuracy by intraluminal manometry. Gastroenterol 70:117-123, 1976.

4) Hurwitz AL, Nelson JA. Haddad JK : Oropharyngeal dysphagia : Manometric and cine esophagographic findings. Am J Dig Dis 20:313-324. 1975.

5) Palmer ED : Disorders of the cricopharyngeal muscle: a review. Gastroenterol 71:510-519, 1976.

6) Newman A: Manometry in the evaluation of esophageal function. Otolaryngol Clin North Am $11: 405-417,1978$.

7) McConnel FMS. Cerenco D, Hersh T, Weil LJ: Evaluation of pharyngeal dysphagia with manofluorography. Dysphagia 2:187-195, 1988.

8）森敏裕, 丘村 熙：䁒下圧測定の臨床的意義.日気食 会報 $35 ： 241-249 ， 1984$.

9) Winship DH, Viegas de Andrade SR, Zboralske FF : Influence of bolus temperature on human eso. phageal motor function. J Clin Invest $49: 243-$ 250. 1970.

10）吉田哲二：正常鰙下に関する筋電図的ならびに $\mathrm{X}$ 線的 研究。耳草 $25: 824-872,1979$

11）古川浩三：䁒下に扮ける喉頭運動のX線学的解析一特 に年齢変化について一，日耳鼻 $87 ： 169-181 ， 1984$.

12) Palmer JB, Tanaka E. Siebens AA: Motions of the posterior pharyngeal wall in swallowing. Laryn goscope $98: 414-417,1988$.

13) Wallin L, Boesby S, Madsen T : Comparative pressure measurements in the oesophagus by means of in situ tip-transducers and external transducer systems. Scand J Clin Lab Invest 38:375-381, 1978.

14) Wilson JA. Pryde A. Cecilia CA et al: Normal pharyngoesophageal motility. - A study of 50 
healthy subjects -. Dig Dis Sci 34: 1590-1599, 1989.

15) McConnel FMS : Analysis of pressure generation and bolus transit during pharyngeal swallowing. Laryngoscope 98:71-78, 1988.

16) Dodds WJ, Hogan WJ, Lydon SB et al: Quantitation of pharyngeal motor function in normal human subjects. J Appl Physiol 39:692-696, 1975.

17）小宮山荘太郎, 笠 誠一, 渡辺宏, 金菂秀一郎, 井之口 昭 他：食道の生理と病態 2. 内圧測定上り みた下咽頭頸部食道筋の病態生理。日気食会報 32 ： 89-94, 1981.

18) Sundstroem G, Ulmsten U : Lateral-hole catheters compared with shielded-hole catheter systems in oesophageal manometry. Scand J Clin Lab Invest $37: 661-665,1977$.

19) Green WER, Castell JA, Castell DO : Upper esophageal sphincter pressure recording: Is an oval manometry catheter necessary? Dysphagia 2: 162 $-165,1988$.

20) Sokol EM, Heitmann P, Wolf BS et al: Simultaneous cineradiographic and manometric study of the pharynx, hypopharynx, and cervical esophagus. Gastroenterol 51 : 960-974, 1966.

21）森敏裕, 丘村 熙,稲木匠子：踖下圧伝搬速度の評価 法. 耳鼻臨床 82：1441-1445，1989.

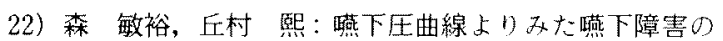
分類の試み。日気食会報 $36: 363-370 ， 1985$.

23）西納真介, 小宫山荘太郎, 渡辺 宏, 廣戸幾一郎: 睘下 圧測定装置の試作とその䠛床的応用. 日気食会報 30 ： 379-383, 1979

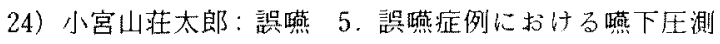
定の意義。日気食会報 $31: 121-125 ， 1980$ 。

25) Fyke $\mathrm{FE}$, Code $\mathrm{CF}$ : Resting and deglutition pressure in the pharyngo-esophageal region. Gastroenterol $29: 24-34,1955$.

26) Dodds WJ, Kahrilas PJ, Dent J et al : Considarations about pharyngeal manometry. Dysphagia 1:209 $-214,1987$.

27）山下弘之, 宮崎 洋, 増田 孝, 笠 誠一, 小宮山荘太郎 四㘳下障害のX線学的所見一輪状咽頭筋切断術加奏功 した1例一。耳鼻 34：98-101，1988.

28) Duranceau A, Rheault MJ, Jamieson GG : Physiologic response to cricopharyngeal myotomy and diverticulum suspension. Surgery 94:655662, 1983.

29) Ellis FHJr: Upper esophageal sphincter in health and disease. Surg Clin North-Am, 51 : 553-565, 1971.

30) Henderson RD, Boszko A, vanNostrand AWP: Pharyngoesophageal dysphagia and recurrent laryn. geal nerve palsy. J Thor Cardiovasc Surg 68: 507-512, 1974.

31) Hurwitz AL, Duranceau A, Haddad JK : Oropharyngeal dysphagia, Chapt. 7 in Major Problems in Internal Medicine Vol XVI; Disorders of esophageal motility. W.B. Saunders Co., 1979, pp67-84.

32) Nilsson ME, Isberg A, Schiratzki H: The Hypopharyngeal diverticulum. A simultaneous cineradiographic and manometric exramination. Acta Otolaryngol 106:314-320, 1988.

33) McConnel FMS, Cerenko D, Jackson RT et al: Timing of major events of pharyngeal swallowing. Arch Otolaryngol Head Neck Surg 114: 1413$1418,1988$.

34) Seaman WB: Pharyngeal and upper esophageal dysphagia. JAMA 235:2643-2646, 1976.

35) Black RJ : Cricopharyngeal myotomy. J Otolaryngol $10: 145-148,1981$.

36) Kagen LJ, Hochman RB, Strong EW : Cricopharyngeal obstruction in inflammatory myopathy (polymyositis/dermatomyositis). Report of three cases and review of the literature. Arthritis Rheum 28:630-636, 1985.

37) Hurwitz AL: Normal esophageal motility, Chapt 3 in Major Problems in Internal Medicine Vol XVI; Disorders of esophageal motility. W.B. Saunders Co., 1979, pp14-26.

38）啮沢三伸, 辺士名仁, 矢野一彦,市川容子, 河野辰幸他: 嚾下圧波形と签状咽頭筋の筋電図との関係。日気食会 報 40：9-15，1989.

稿を終えるにあたり、ご校閲を賜った柳原尚明教授、並び に直接のご指導、ご校閲を賜った丘村 熙助教授に深甚な 万謝意を表します。また研究にご協力頂いた稻木匠子先生， 福井康二先生，池内浩二技官はじ教室の諸先生方に深謝 いたします。

な㧍本論文の要旨は，第90回日本耳星咽堠科学会総会に 扔いて発表した。

(1991年11月29日受稿 1992年2月3日受理)

別刷請求先 干791-02 要媛罢温泉郡重信町志津川

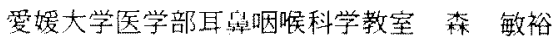




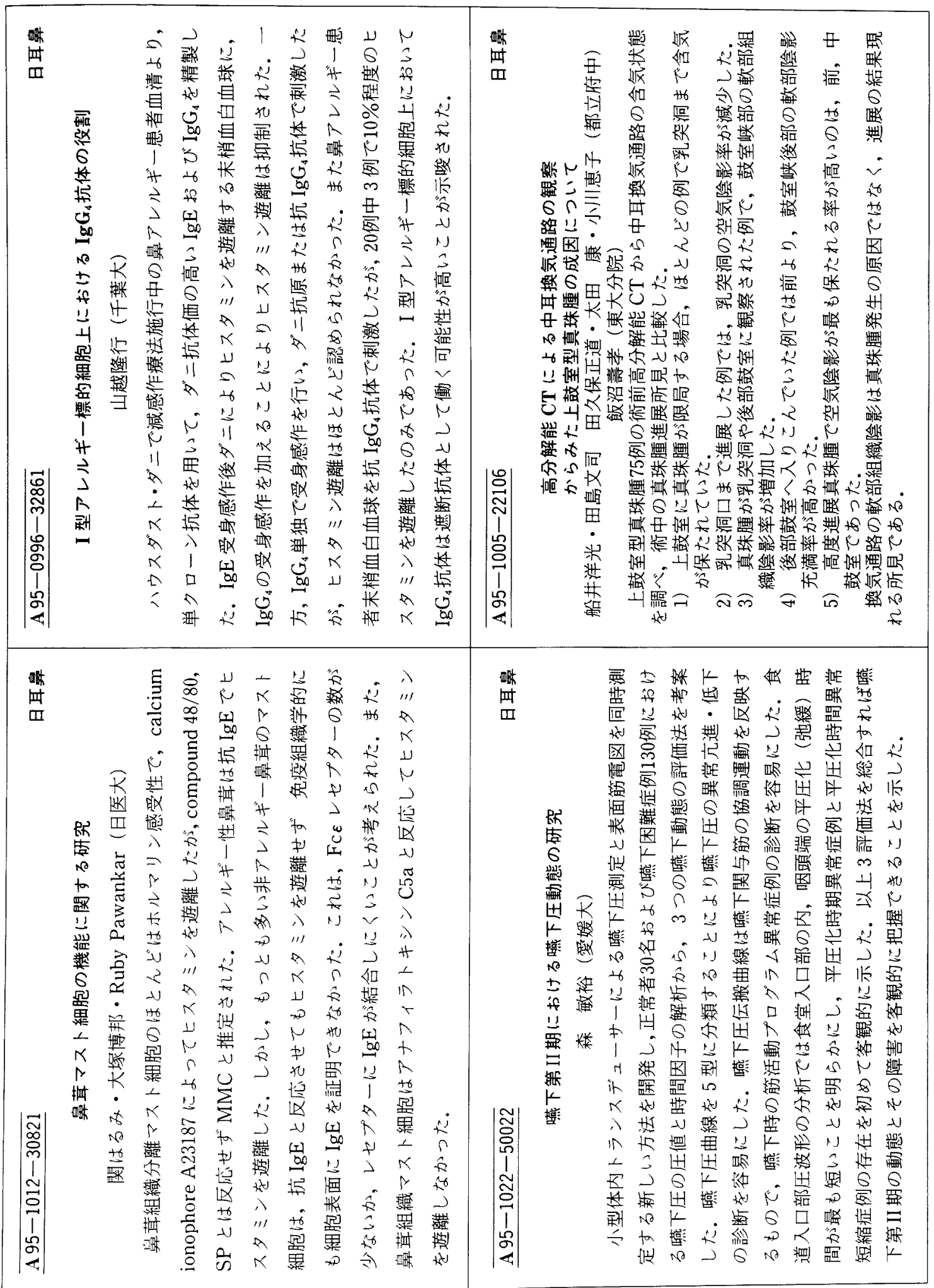

